\section{The moderating effect of agglomeration on horizontal differentiation and online reviews: the case of Paris hotels}

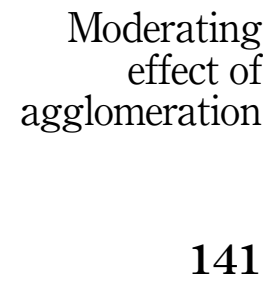

María D. Illescas-Manzano

Department of Economics and Business, CIMEDES Research Center, University of Almería, Almeria, Spain

Sergio Martínez-Puertas

Math Department, CIMEDES Research Center, University of Almeria, Almería, Spain, and

Manuel Sánchez-Pérez

Department of Economics and Business, CIMEDES Research Center, University of Almería, Almería, Spain
Received 27 May 2021 Revised 22 July 2021 4 August 2021

Accepted 5 August 2021

\begin{abstract}
Purpose - Hotels are immersed in a very competitive environment and hoteliers have to plan and redesign their strategies to stay in the hospitality industry while faced with a steady rise in competition. Hoteliers can employ horizontal differentiation strategies and pricing decisions to gain a competitive advantage over their competitors. The goal of our work is to analyse the effect of pricing and horizontal differentiation strategy of a hotel on its online reputation and to analyse if the hotel location and agglomeration of competitors moderates their relationship with online reputation.

Design/methodology/approach - With a sample of 264 hotels from Paris, an empirical study is developed that aims to analyse, using regression techniques, the impact of price, differentiation, location and competitive environment on online ratings given by consumers in the hospitality context.

Findings - The paper provides empirical evidence of how a good location improves the online reputation of a company and how pricing strategies should take into account the location and number of competitors since a good location allows premium prices to be valued positively by consumers while an inappropriate location can produce the opposite effect. Depending on location, the number of competitors can intensify or reduce the effect of price on online reputation. Finally, online reputation only benefits from horizontal differentiation strategies when the degree of agglomeration is low.

Originality/value - This work provides insights about how hotels can strengthen their online reputation through pricing and differentiation strategies, incorporating elements of their environment such as location and competition in this decision-making process.
\end{abstract}

Keywords Online rating, e-WOM, Price, Horizontal differentiation, Competence, Location

Paper type Research paper

(C) María D. Illescas-Manzano, Sergio Martínez-Puertas and Manuel Sánchez-Pérez. Published in European Journal of Management and Business Economics. Published by Emerald Publishing Limited. This article is published under the Creative Commons Attribution (CC BY 4.0) licence. Anyone may reproduce, distribute, translate and create derivative works of this article (for both commercial and noncommercial purposes), subject to full attribution to the original publication and authors. The full terms of this licence may be seen at http://creativecommons.org/licences/by/4.0/legalcode

This work was supported by the Spanish Ministry of Science and Innovation, project PID2020119994RB-I00, and University of Almería.

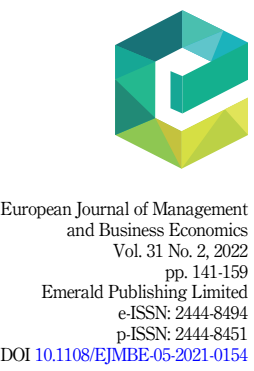


EJMBE 31,2

\section{Introduction}

Online consumer review (OCR) is considered the most relevant way in which eWOM occurs (Kim et al., 2018b), playing an essential role in recommender systems (Verma and Yadav, 2021). Indeed, when planning a purchase, $51 \%$ of French consumers always do some research on the Internet first, with $41 \%$ finding customer online reviews very helpful when planning a purchase (Statista, 2020). Indeed, it has become critical for a firm's performance (Xie et al., 2016), with an expanding relevance under the New Normal (Arora et al., 2020).

Extant literature has evaluated eWOM across several industries and settings (Kitirattarkarn et al., 2020). Without pretending to be exhaustive, a literature review reveals that research has primary focused on senders' messages and channel related variables, such as the antecedents of a sender's reviews (e.g. Kim et al., 2018a), the consequences for receiver's attitude and behaviours (e.g. Flanagin and Metzger, 2013; Wakefield and Wakefield, 2018), the cognitive information structure of the review (Ruiz-Mafe et al., 2020), the consequences of the review for the receiver (e.g. Yoon et al., 2019), the role of platforms in online review activity (Lee and Youn, 2009), the influence of brand awareness (Stojanovic et al., 2018) or its effects on firm performance (Kim et al., 2015; Ladhari and Michaud, 2015). However, a systematic review performed by Rosario et al. (2020) reveals that understanding how product characteristics shape eWOM search behaviour remains underanalysed.

Consumer review behaviour is conceived as a way of engagement, in which firm attributes and competitive alternatives induce reviews, either requesting higher quality or affecting the perceived value of the products (Van Doorn et al., 2010). Specifically, firm-based contributions have mainly focused on factors such as brand engagement (Hollebeek et al., 2014), customer service (e.g. Prentice et al., 2019), consumer information or consumer loyalty (So et al., 2016). Consequently, most of the previous studies focused on the analysis of the determining factors of online rating adopt a consumer perspective while the analysis of the role played by product characteristics or the location of a service in the online reputation are scarce. Likewise, although eWOM reviews have called for further investigation into the influence of the competitive environment on online reviews (see You et al., 2015), there are few studies that address this relationship.

The purpose of our study is to fill this gap and try to analyse the impact of price, differentiation, location and competitive environment on online ratings given by consumers in the context of hospitality with a sample of 264 Parisian hotels, since it is a sector where pricing (Abrate et al., 2012), location (Fang et al., 2019) and competition (Becerra et al., 2013) are very relevant aspects and hotels can horizontally differentiate their services according to customer preferences (Neirotti et al., 2016). Also, economic outcomes in the hotel industry are influenced by online reviews (Yang et al., 2018b). Specifically, we have focused on urban tourism because location plays a relevant role when tourists seek a good location to the detriment of other attributes or additional services (Yang et al., 2018a) and we have contextualized our study in the Parisian hotel industry, as it is a relevant case of a city with a special interest for urban tourism research (Pearce, 1999), in the year 2017 when Paris was the second European city in bednights (European cities, 2018) and the one with the highest value (HVS, 2018).

Additional arguments justify our analysis. Firstly, from a company perspective, rating is an information rich OCR cue because high review ratings can act as a substitute for advertising spending (Hollenbeck et al., 2019). Secondly, contributions to the literature regarding the effect of product attributes are very limited and generic. Previous findings show that product category has been revealed to moderate the influence of online review motivators on sales (Li et al., 2020), and product characteristics have been identified as being a determinant of consumer review creation (Rosario et al., 2020). However, existing research about product differentiation and online review has only found an indirect effect of 
differentiation on online reviews through the dispersion of ratings (Clemons et al., 2006). Product attributes such as horizontal differentiation strategy (Makadok, 2010) driven to specific segments has not been examined.

Thirdly, closely related to product evaluation is pricing, since it is linked to the product quality evaluation and affects user ratings as a quality cue (De Langhe et al., 2016). Though literature supports the existence of a negative effect of price on eWOM (Masiero and Nicolau, 2016), the effect of price in hospitality does not have a straightforward effect, being influenced by trigger points' as price is the reason behind a stay (Lockyer, 2005). Also, previous studies have identified a self-selection bias in online reviews for early consumers that could benefit firms but may decrease consumer surplus (Li and Hitt, 2008).

Finally, although the previous literature has provided evidence that competitive intensity can transfer to the online environment (You et al., 2015), there are few previous studies that address this issue (Gutt et al., 2019; Liu et al., 2018) and these do not take into account how physical distance can play a relevant role in OCRs, since the physical distance between users conditions the effectiveness of OCR and, as a consequence, of the advertising and communication strategy (Todri et al., 2021) and based on the literature of spatial competition, a shorter distance between competitors can intensify rivalry (Lee, 2015) even in the online environment (Mayzlin et al., 2014).

Theoretically, this work aims to contribute to the literature on the influence of firm's marketing decisions on online review literature. Firstly, it extends the previous studies about OCRs by incorporating a competition perspective to explain the online review ratings. Secondly, it helps firms to adopt marketing actions according to the perceived value generated for the customer, meeting Kannan and Li's call (2017). And thirdly, our study aims to clarify the importance and role of location on the generation of online ratings.

\section{Literature review}

\subsection{Importance of online rating in tourism and hospitality}

The advance of information technology, a key factor for the development of sectors such as tourism (Liberato et al., 2018), has promoted the popularity of OCRs among consumers (Plotkina and Munzel, 2016) who consider this to be an essential tool to evaluate alternatives in their decision making process when purchasing products online and offline (Park and Nicolau, 2015). This common form of electronic word of mouth (eWOM) (Kim et al., 2018b) can impact on the purchase decisions of consumers (Filieri and McLeay, 2014) and foster the sales of products in different industries (Chevalier and Mayzlin, 2006; Li et al., 2019; Oğüt and Onur Taş, 2012).

The hospitality industry has not been an exception to this phenomenon since it is a service industry that, due to the intangible nature of experience goods, presents a high information asymmetry (Manes and Tchetchik, 2018) and consequently consumers frequently employ OCRs to support their decision-making process (Gretzel and Yoo, 2008; Tiago et al., 2021), which, as in other industries, translates into an impact on sales (Öğ̈ut and Onur Taş, 2012). Thereby, OCRs constitute a reliable source of information in the hospitality industry not only for consumers (Yen and Tang, 2019) but also for managers (Torres et al., 2014).

The OCRs generally count with a numerical rating, mainly explained by service quality and the lodger's experience, that provide a general landscape of the attitude of consumers towards the product and the service consumed (Park and Nicolau, 2015). Extensive literature has highlighted the role that OCR ratings play in hospitality since a higher online rating can increase the monetary value of a company (Jang et al., 2012), hotel performance (Yang et al., 2018b), occupancy (Viglia et al., 2016), sales (Ögüü and Onur Taş, 2012), revenues of companies (Neirotti et al., 2016) and the willingness to pay (Nieto-Garcia et al., 2017). Consequently, the hospitality context is an appropriate framework for OCR research since 
EJMBE 31,2 hotels continually seek ways to enhance their online reputation to improve their competitiveness and profitability (Tiago et al., 2021).

Despite the importance of a high rating in the hospitality context, research on the characteristics that influence the rating of OCRs mainly takes an approach based on consumer characteristics (Leung and Yang, 2020; Li et al., 2021; Xue et al., 2020; Yeng and Tang, 2019) with scarce previous studies that adopt an approach that encompasses the characteristics of the product and the strategic decisions of the company (Radojevic et al., 2017; Yeng and Tang, 2019). For this reason, this work aims to analyse whether price, horizontal differentiation, location and agglomeration affect the online rating, given the value of a high rating both from the perspective of the company and the consumer in the hospitality industry.

\subsection{Price and OCRs}

Previous literature considered that product price can negatively impact on online ratings since it is likely that low price generates positive reviews from consumers who share their satisfaction with the low prices they pay (You et al., 2015). Additionally, price can act as a prepurchase quality cue (Wolinsky, 1983) that consumers can employ in the face of an uncertain purchase (Völcker and Hoffman, 2007) and consequently, based on the expectation disconfirmation theory (EDT) (Oliver, 1980) which postulates that the customer's experience with the product can lead to negative disconfirmation if it falls below expectations, while if the experience exceeds expectations positive disconfirmation occurs, price being a key factor that influences the consumers post-purchase satisfaction (Varki and Colgate, 2001) due to confrontation between expectations and the received quality postconsumption (Abrate et al., 2021). Since OCRs can be driven by disconfirmation which influence ratings (Ho et al., 2017), under this approach, price can impact negatively on online ratings of products and services (Li and Hitt, 2010; Abrate et al., 2021).

In the hospitality context, price has been considered as an essential factor for customer choice (Gupta et al., 2007). Furthermore, a reasonable price level is a critical factor that impacts on customer satisfaction (Pantelidis, 2010) and due to the existence of a significant relationship between consumer-generated ratings and customer satisfaction (Torres et al., 2014), consumer reviews of products and services take price paid into account with a negative effect on online ratings (Ye et al., 2014).

Despite some conflicting results (Martin-Fuentes, 2016; Radojevic et al., 2017), this negative effect of the price on the online rating has found empirical evidence in hospitality research (Abrate et al., 2021; Zhang et al., 2014; Zhu et al., 2019; Ye et al., 2014). Thus, Ye et al. (2014) and Abrate et al. (2021) find that price impacts negatively on value perception of consumers about hospitality services and consumers take price into account negatively in their online ratings. The negative effect of price on ratings in the hospitality industry is also confirmed by Zhang et al. (2014). Zhu et al. (2019) found that consumers who enjoy a price reduction tend to give higher online scores when evaluating a hospitality service. Due to the above reasons, we establish the following hypothesis about the influence of price on online ratings:

H1. The price of hospitality products or services has a negative impact on online ratings provided by consumers.

\subsection{Horizontal differentiation and OCRs}

Horizontal differentiation is based on the heterogeneity of consumer preferences in the selection of the set of desirable attributes in a product or service so that although the products are offered at the same price, each will have a different market share (Makadok, 2010).

Nowadays, companies engage in the development of innovations to seek or generate new markets (Tiberius et al., 2021), and they are able to produce any product that a consumer 
might want, something which can lead to consumer overload due to the wider offer. Although OCR platforms allow companies to promote their sales through appropriate horizontal differentiation strategies since they make it easier for consumers to search for a product with characteristics which meet their preferences (Clemons et al., 2006), there are some reasons to justify that horizontal differentiation strategies can be harmful to online reputation (Li and Hitt, 2008; Liu et al., 2018).

First, although there is empirical evidence that horizontal differentiation strategies can foster a greater volume of eWOM (Lovett et al., 2013), an inappropriate degree of differentiation between competitors in a commercial zone can have the opposite effect (Liu et al., 2018). Second, horizontal differentiation can enhance the effect of positive self-selection bias (bias generated by wrong decisions that did not meet expectations due to different preferences with respect to previous consumers) so that its main effect is the reduction of the average rating of a product or service (Li and Hitt, 2008). Finally, within the hospitality industry, it has been found that the less horizontally differentiated companies have a higher benefit from the effect of online rating on economic results (Manes and Tchetchik, 2018) so that OCRs can discourage companies from adopting horizontal differentiation strategies.

However, to the best of our knowledge, there are few previous studies that have analysed the impact of horizontal differentiation strategies on OCRs in the hospitality industry (Manes and Tchetchik, 2018; Radojevic et al., 2017) and few studies have considered alternatives to incorporating competition in the measurement of horizontal differentiation (Urtasun and Gutiérrez, 2017).

Due to the aforementioned reasons and given that horizontal differentiation is evaluated by consumers based on their subjective preferences, we establish the following hypothesis:

H2. The horizontal differentiation of products and services has a negative impact on online ratings provided by consumers.

\subsection{Location and OCRs}

Location is an essential factor and long-term strategic decision for the success of a company in the hospitality industry (Fang et al., 2019; Yang et al., 2012) since a good location is associated with higher occupation, higher income and profitability (Lado-Sestayo et al., 2016; Luo et al., 2016; Yang et al., 2014) and lower failures (Parsa et al., 2011) and it allows the payment of fixed capital investments to be reduced (Chou et al., 2008). A good location, in addition to improving the profitability of the company can also influence consumer choice (Masiero et al., 2019) and customer behaviour (Shoval et al., 2011).

Moreover, location is one of the key factors that positively influence customer satisfaction (Xu and Li, 2016), particularly in urban tourism, where tourists, as essential actors in the maintenance of high street vitality (García-Milon et al., 2021), need accessible hotels close to the main attractions of the urban area (Ritter, 1986) in order to maximize their utilities and optimize their trip duration (Yang et al., 2018a) and do not require additional services that can entail a higher price (Liu et al., 2020), and hence location can influence the customer evaluations through OCRs (Aksoy and Ozbuk, 2017). A convenient location is associated with positive comments and higher online ratings and it is therefore a critical success factor (Fuentes-Medina et al., 2018). Thus, several previous studies in the hospitality industry have confirmed a positive effect of location on online ratings (Radojevic et al., 2017; Yang et al., 2018a). Therefore, we consider the following hypothesis:

\section{H3. A good location has a positive effect on the online rating}

On the other hand, the location of the hotel also has a positive influence on the price of the product or service (Chen and Rothschild, 2010) and the client's willingness to pay (Aznar, 2020). Thus, based on EDT, through a convenient location, hotels can exceed expectations of 
EJMBE 31,2 customers and can turn the disconfirmation related to price from negative to positive. For these reasons, we establish the following hypothesis:

H4. A good location mitigates the negative effect of price on the online rating of consumers.

\subsection{Competence and OCRs}

The hospitality literature has highlighted the relevant role of the competitive environment in the performance of a company (Abrate et al., 2012; Becerra et al., 2013; Falk and Hagsten, 2015; Lee, 2015; Lee and Jang, 2015; Marco-Lajara et al., 2016), although there are contradictory findings in this regard that can be supported by the confrontation framework of two opposite effects: agglomeration versus competition (Lu et al., 2017). Thus, the hospitality literature has provided empirical support for the theoretical argument (Shaked and Sutton, 1982) from the Industrial Organization approach that suggests that a higher level of competition can negatively affect the performance of hospitality companies since it can decrease the price of a service (Abrate et al., 2012; Becerra et al., 2013; Falk and Hagsten, 2015), but on the other hand, previous studies (Lee and Jang, 2015; Marco-Lajara et al., 2016) have also supported the theoretical arguments from agglomeration theories (McCann and Folta, 2008) that postulate benefits associated with a greater concentration of competitors such as the improvement in the innovation performance of the company (Turkina et al., 2019).

Further, the marketing literature has analysed how the competitive environment can affect the online environment, that is, the eWOM generated by consumers (Gutt et al., 2019; Liu et al., 2018; Luca and Zerbas, 2016; Mayzlin et al., 2014; Neirotti et al., 2016; You et al., 2015). Thus, the competitive environment can moderate both the effect of rating on sales (You et al., 2015) and the effect of the rating on revenues and profitability (Neirotti et al., 2016).

Given the aforementioned importance of the competitive environment in the hospitality industry, most of the previous studies that have analysed the relationship between competition and OCR have used this industry as a study framework (Gutt et al., 2019; Liu et al., 2018; Luca and Zerbas, 2016; Mayzlin et al., 2014; Neirotti et al., 2016). Despite a higher level of competition being able to generate a greater volume of OCRs (Liu et al.,2018), based on EDT, when there are few alternatives, consumers have low expectations about their ability to match their preferences (Diehl and Poynor, 2010), which can stimulate the occurrence of positive disconfirmation. In fact, it has been found that markets with a greater number of competitors have a lower average online rating (Gutt et al., 2019) and when a company faces a greater number of competitors, it is more likely to suffer negative fake reviews (Luca and Zerbas, 2016). Although these previous studies have not analysed the impact of competition on the rating of OCRs at the company level, they suggest that the competitive environment can negatively affect online ratings. Therefore, we establish the following hypothesis:

H5. The number of competitors of a hospitality company has a negative impact on online ratings provided by consumers.

Concerning the effect of distance on OCRs, hospitality research has found empirical support (Lee, 2015) for the postulates of spatial competition theory (Pinkse et al., 2002), which states that competitive intensity increases with smaller distances. Additionally, competitive intensity can overlap to the online environment because a smaller distance to competitors also increases the probability of online fake reviews so hotels with close competitor neighbours are more likely to suffer negative fake review attacks from nearby competitors than hotels in isolated areas (Mayzlin et al.,2014), and this can cause an attacker to overshadow its competitors in terms of online visibility (Lappas et al., 2016). Due to these reasons, we establish:

H6. Distance from competitors has a positive effect on the online rating of consumers. 
On the other hand, in the hotel industry several results support that a higher number of hotels entails a reduction of average room price (Abrate et al., 2012; Becerra et al., 2013; Falk and Hagsten, 2015) due to the fact that a large number and concentration of hotels allows consumers to access higher quality (Lee, 2015). Consequently, we assume that a greater number of competitors increases the negative effect of price on online rating:

$H 7 a$. The number of competitors intensifies the negative effect of price on the online rating of consumers.

Finally, it has been found (Sanchez-Pérez et al., 2020) that the benefits associated with horizontal differentiation in the hospitality industry are conditioned by the degree of agglomeration, perhaps due to the higher cost associated with horizontal differentiation together with the fact that this type of differentiation hinders collaboration between competitors (Silva, 2015). Furthermore, hotels that are less horizontally differentiated have lower costs of manipulation and are more likely to engage in review manipulations against differentiated hotels (Mayzlin et al., 2014), with the consequent loss of online visibility (Lappas et al., 2016) that may encourage differentiated hotels to locate far away from the competition to avoid attacks (Lappas et al., 2016). Consequently:

$H 7 b$. The distance from competitors mitigates the negative effect of horizontal differentiation on the online rating of consumers.

\section{Methodology}

\subsection{Research setting}

We will carry out an empirical analysis in which we will consider the Paris hotel industry in 2017 as a frame of reference. There are several reasons for choosing the hotel industry as a framework to explore the factors that enable the improvement of online rating. Firstly, an increase in online rating can provide several benefits in the hotel industry. Hotels with higher online ratings can benefit from higher sales (Öüut and Onur Taş, 2012), higher occupancy rate (Viglia et al., 2016) and higher hotel performance (Yang et al., 2018b). Secondly, the hotel industry offers a framework in which services may exhibit horizontal differentiation in terms of customer preference (Neirotti et al., 2016), and it is an industry with intensive horizontal competition (Liu et al., 2020). Additionally, pricing (Abrate et al., 2012), competition and agglomeration (Becerra et al., 2013) and location (Fang et al., 2019) also play a key role for success in the hotel industry. Concerning the Parisian tourist sector in 2017, Paris was ranked as the second European city in international arrivals and the sixth city worldwide with 15.8 million (Euromonitor, 2018). Furthermore, Paris was ranked as the second European city in bednights with 48.1 million (European cities, 2018) and the Parisian hotel industry topped the Hotel Valuation Index in 2017 (HVS, 2018) which indicates that the hotel sector in Paris is a strong and consolidated sector that has been considered as a framework in the previous literature on OCRs (Öğüt and Onur Taş, 2012).

The sample includes 264 hotels located in Paris and has been obtained from the information system of an international Group Travel Agencies (GTA) and the commercial areas defined by GTA are considered as areas of geographic competition between hotels for a correct measurement of the horizontal differentiation of a hotel with respect to its competitors. All statistical analysis has been performed with the statistical software $R$ Version 4.0.3. Table 1 shows the main descriptive statistics for all variables in the sample.

\subsection{Models and variables}

We propose two models to test the hypotheses established in the work: 


\begin{tabular}{llccccccc} 
EJMBE & & Min & Q1 & Median & Q3 & Max & Mean & SD \\
\cline { 2 - 9 } 31,2 & Score & 6.300 & 8.180 & 8.560 & 8.920 & 9.920 & 8.505 & 0.643 \\
& Size & 7 & 29 & 48 & 47 & 1025 & 50.05 & 91.259 \\
& Age & 1 & 11 & 13 & 18 & 218 & 25.33 & 38.579 \\
& Price & 50.55 & 100.10 & 125.30 & 157.60 & 1270 & 125.30 & 99.608 \\
& Differentiation & 0 & 0.524 & 1.550 & 2.612 & 12.220 & 1.814 & 1.870 \\
$\mathbf{1 4 8}$ & Location & 1 & 2.750 & 3 & 4 & 5 & 3.201 & 0.873 \\
\hline Table 1. & N_Comp & 3 & 53 & 77 & 129 & 155 & 84.75 & 41.821 \\
Sample descriptive & Distance & 0 & 0.700 & 0.875 & 1.060 & 4.110 & 0.941 & 0.406 \\
statistics & Congress & No & Yes & & & & & \\
\hline & \% & 96.59 & 3.41 & & & & & \\
\hline
\end{tabular}

Model 1:

$$
\begin{aligned}
\text { Score }_{i}= & \alpha_{0}+\beta_{1} \text { Size }_{i}+\beta_{2} \text { Age }_{i}+\beta_{3} \text { Congress }_{i}+\beta_{4} \text { Price }_{i}+\beta_{5} \text { Differentiation }_{i} \\
& +\beta_{6} \text { Location }_{i}+\beta_{7} N_{-} \text {Comp }_{i}+\beta_{8} \text { Distance }_{i}+\varepsilon_{i}
\end{aligned}
$$

Model 2:

$$
\begin{aligned}
\text { Score }_{i}= & \alpha_{0}+\beta_{1} \text { Size }_{i}+\beta_{2} \text { Age }_{i}+\beta_{3} \text { Congress }_{i}+\beta_{4} \text { Price }_{i}+\beta_{5} \text { Differentiation }_{i} \\
& +\beta_{6} \text { Location }_{i}+\beta_{7} N_{-} \text {Comp }_{i}+\beta_{8} \text { Distance }_{i}+\beta_{9} \text { Price }_{i} \cdot \text { Location }_{i} \\
& +\beta_{10} \text { Price }_{i} \cdot N_{-} \text {Comp }_{i}+\beta_{11} \text { Differentiation }_{i} \cdot \text { Distance }_{i}+\varepsilon_{i}
\end{aligned}
$$

where Score denotes the dependent variable that measures the yearly average online rating of each hotel. This rating from consumers consists of a score between zero and ten, where zero represents the worst rating and ten represents the best rating (Manes and Tchetchik, 2018).

Among the independent variables, we distinguished between:

Control variables. We used the following variables to control for the potential effects of differences between hotels:

(1) Size. Large company size can result in a deterioration of the services offered which results in a negative impact on the online valuation of customers (Radojevic et al., 2017), so we control for the size of the hotel by the number of rooms.

(2) Age. We controlled for the age of the hotel by the number of the operation years since old facilities may be the source of dissatisfaction among consumers regarding a product or service (Xu and $\mathrm{Li}, 2016)$.

(3) Congress. Given the different preferences between business travellers and leisure travellers and that business travellers report significantly lower levels of satisfaction than leisure travellers (Radojevic et al., 2017), we controlled whether the hotel is a congress hotel through a dummy variable.

Explanatory variables. To test the hypotheses established in the previous section, we considered the following variables:

(1) Price. The yearly average room rate for a standard double room in 2017 for each hotel (Lee, 2015).

(2) Differentiation. This variable accounts for the horizontal differentiation based on the service offer of each hotel with respect to the remaining hotels in the same commercial 
area. We considered a distance applied in product differentiation literature (Chisholm et al., 2010). Specifically, each hotel is represented by a vector of services $V_{i}$ that indicates with 1 the availability of the service while with the value 0 it indicates the absence of a service. The services considered in $V_{i}$ includes hotel style, sports effect of activities and food services. Specifically, for a hotel in the area $A_{i}$ is defined as:

$$
\text { (Differentiation })_{i}=\sum\left(V_{i}\right) * \operatorname{mean}_{j \text { in } A_{i}}\left(d\left(V_{i}, V_{j}\right)\right)
$$

where $d\left(V_{i}, V_{j}\right)$ is the differentiation of hotel $V_{i}$ respect to $V_{j}$. It takes the value 0 if hotel $V_{j}$ offers more services than hotel $V_{i}$ and all services offered by $V_{i}$. Otherwise, it takes the following value:

$$
d\left(V_{i}, V_{j}\right)=\frac{\left(\cos ^{-1} \frac{V_{i} \cdot V_{j}}{\left\|V_{i}\right\| \cdot\left\|V_{j}\right\|}\right)}{\left(\frac{\pi}{2}\right)}
$$

(1) Location. A valuation of Parisian hospitality commercial zones (Mona, 2020) based on transport nodes, externalities or attractions. It ranges from 1 (the worst valuation) to 5 (the best valuation).

(2) N_Comp. The total number of hotels in the same commercial area (Becerra et al., 2013).

(3) Distance. The average distance of each hotel with respect to other hotels located in the same area in kilometres (Becerra et al., 2013).

Model 1 includes all the main effects of the explanatory variables to contrast the hypotheses about direct effects ( $\mathrm{H1}, \mathrm{H} 2, \mathrm{H} 3, \mathrm{H} 5$ and H6), whereas Model 2, in addition to the main effects, also includes the interaction terms to contrast hypotheses $\mathrm{H} 4, \mathrm{H} 7 \mathrm{a}$ and $\mathrm{H} 7 \mathrm{~b}$ related to moderating effects. Both models were estimated with OLS and bootstrap methods were used to estimate standard errors (Davison and Hinkley, 1997). Table 2 provides the results obtained in the estimation of the two models using OLS. The adjusted $R^{2}$ value from Model 2 shows a better adjustment than Model 1. To test the significance of Model 2 versus Model 1, we conducted an $F$-test, the results of which confirmed the significance of Model 2 versus Model 1 ( $p$-value 0.014).

\section{Results}

The results of Model 1 show that only price and horizontal differentiation have an effect on online ratings but, from Model 1, only hypotheses $\mathrm{H} 2$ is confirmed, since Differentiation has a negative effect whereas Price has a positive effect.

Now, since Model 2 fits significantly better than Model 1, we will focus on the results obtained in Model 2 which shows different results compared to Model 1. Although the results of Model 2 also confirm the hypotheses H2, unlike Model 1 it does confirm the hypothesis H1 and H3. Therefore, according to Liu et al. (2018), horizontal differentiation may harm some cues related to online reputation. Price has mainly a negative effect on rating as seen in the results of previous studies in the hospitality context (Zhang et al., 2014; Zhu et al., 2019; Ye et al., 2014) and contrasting with the results from Martin-Fuentes (2016) and Radojevic et al. (2017). Also, the location of a hotel positively influences the online rating in accordance with previous hospitality studies (Radojevic et al., 2017; Yang et al., 2018a). Additionally, the interaction between price and location is significant and its coefficient is positive which confirms the hypothesis $\mathrm{H} 4$ and consequently the location mitigates the negative effect of price on online rating. To better illustrate this moderation effects, Figure 1 displays the effect 


\begin{tabular}{|c|c|c|c|}
\hline & & & \\
\hline $\begin{array}{l}\text { EJIMBBE } \\
212\end{array}$ & & Model 1 & Model 2 \\
\hline & Intercept & $8.277 * * *$ & $8.055^{* * * *}$ \\
\hline & Size & $9.2 \mathrm{E}-6$ & $8.6 \mathrm{E}-6$ \\
\hline & Age & $-7.4 \mathrm{E}-4$ & -0.001 \\
\hline & Congress & $0.435^{*}$ & 0.316 \\
\hline & Price & $7.8 \mathrm{E}-4^{*}$ & $-0.008^{* *}$ \\
\hline 150 & Differentiation & $-0.052^{*}$ & $-0.056^{* *}$ \\
\hline & Location & 0.062 & $0.129 * *$ \\
\hline & N_Comp & $2.5 \mathrm{E}-5$ & -0.001 \\
\hline & Distance & 0.023 & 0.022 \\
\hline & Price $\times$ Location & & $0.003^{* * *}$ \\
\hline & Price $\times N$ Comp & & $-3.7 \mathrm{E}-5^{* *}$ \\
\hline & Differentiation $\times$ Distance & & $0.073^{*}$ \\
\hline & $R^{2}$ & 0.054 & 0.093 \\
\hline & Adjust $R^{2}$ & 0.025 & 0.054 \\
\hline Models estimation & $\operatorname{Note}(\mathbf{s}): * 10 ; * * 5 ; * * * 1 \%$ & & \\
\hline
\end{tabular}

of price on online rating for two levels of location and two levels of number of competitors. For both Location and $N_{-}$Comp, Figure 1 shows the effect of price for the mean \pm one standard deviation. Regardless of the number of competitors, Figure 1 shows how location changes the effect of price on rating when hotels face low competition (black and blue lines) and high competition (red and green lines). Therefore, a good location can change the negative effect of price to a positive one, thus reconciling previous contradictory results on the price effect by linking its effect with location.

Regarding competition, results from Model 2 do not confirm the hypotheses H5 or H6. Consequently, the competition environment does not directly influence the online ratings at company level contrary to those at market level (Gutt et al., 2019), unlike other online reputation indicators (Liu et al., 2018).

However, because hypotheses H7a and H7b are confirmed by the results of Model 2, the competition environment influences the online rating indirectly through both $N \_$Comp and Distance, so that the effect of price and horizontal differentiation is moderated by the competitive environment of hotels. Figure 1 also displays the moderation effects related with $\mathrm{H} 7 \mathrm{a}$ and $\mathrm{H} 7 \mathrm{~b}$ and it shows how a higher number of competitors intensifies the negative effect of price on ratings when location has a low value (black and red lines) and how it moderates the positive effect of price when location has a high value (green and blue lines). It is worth highlighting the key role of location, since it can counteract the negative effect associated with price even if it is accentuated by a high number of competitors. The stronger positive effect of price occurs with the combination of low competition and high location, whereas the stronger negative effect occurs with the combination of high competition and low location. Finally, the distance to competitors changes the effect of horizontal differentiation on rating. Thus, horizontal differentiation has a negative effect in agglomerated areas (small distance between competitors), which may be due to the fact that hotels have more fake negative reviews from nearby competitors with less differentiation (Mayzlin et al., 2014) while it has a positive effect in isolated areas (large distance between competitors).

\section{Conclusion, limitations and future research}

The present work tries to provide some theoretical and practical contributions. Firstly, compared to other theoretical contributions our study, through the horizontal differentiation index, overcomes the limitations of previous studies in the hospitality context which 


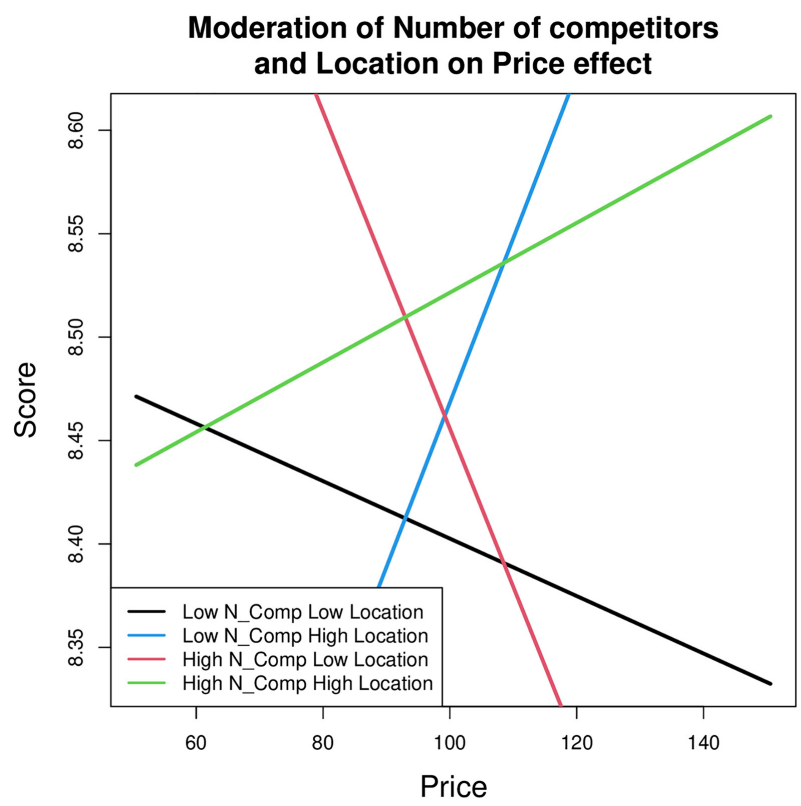

Moderating
effect of
agglomeration

Moderation of Distance on Differentiation effect

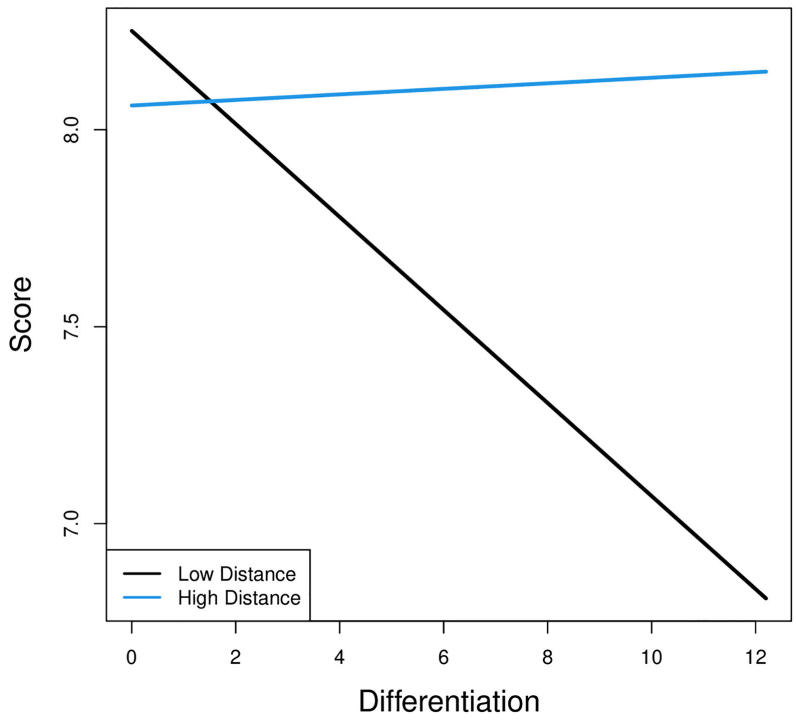

Figure 1.

Moderating effects on the impact of price and

horizontal differentiation on online rating

individually analysed how the availability of a service affects online reputation (Radojevic et al., 2017) and it complements previous studies on the negative impact of differentiation in other online reputation metrics (Liu et al., 2018) concluding with a negative effect on the rating subject to the competitive environment in such a way that horizontal differentiation strategies benefit online reputation when the degree of agglomeration is low. In this way, our 
EJMBE 31,2 study contributes to the analysis of variables not directly related to management that influence the success of innovation strategies (Tiberius et al., 2021).

Regarding the competitive environment, we did not find a direct impact on online reputation at the company level, unlike at the market level (Gutt et al., 2019) or with other metrics (Liu et al., 2018), although indirectly it can negatively affect a consumer's online evaluation through price.

Concerning price, although we conclude with a main negative price effect, based on EDT, our study allows us to reconcile previous studies with contradictory results in the context of hospitality (Zhang et al., 2014; Ye et al., 2014; Radojevic et al., 2017) since the effect of price is linked to the location of services. Consequently, we highlight the role of location in online reputation, but unlike previous studies that only highlighted the direct positive effect of location (Radojevic et al., 2017; Yang et al., 2018a), we also establish how a good location allows a premium price not to necessarily result in a negative user rating even in areas with a high number of competitors.

Next, among the managerial implications, our work shows the convenience of a good location as it improves the online reputation of a company. Additionally, pricing decisions should be subject to the location and the number of competitors. Managers from hotels with a good location can charge a premium price since it does not result in a penalty in the customer valuation. This price premium associated with a good location will be evaluated positively by customers the fewer the number of competitors the hotel has. On the contrary, to compensate for bad location, managers can offer price discounts to improve their online reputation especially if the competitive intensity is high. Additionally, hotel managers will benefit from making marketing decisions based on location as it is implied that customers give more importance to the location of the hotel than to the services that the customer is looking for, since the location choice of the customer replaces the greater differentiation of services offered by a hotel with a higher price.

Finally, this work has several limitations. Firstly, from a methodological point of view, online reputation can show spatial autocorrelation because hotels share externalities. Therefore, future work should consider the use of estimation methods that take spatial autocorrelation into account, for a better modelling of online reputation (Nicholls and Kim, 2019). Secondly, the proposed model does not incorporate characteristics of each customer when evaluating a hotel. Future works should consider whether these characteristics can moderate the relationships proposed with our model. Additionally, future work should consider alternative ways of evaluating locations that are not based on third-party evaluations, by defining an appropriate index that encompasses different types of location factors.

\section{References}

Abrate, G., Fraquelli, G. and Viglia, G. (2012), "Dynamic pricing strategies: evidence from European hotels”, International Journal of Hospitality Management, Vol. 31 No. 1, pp. 160-168, doi: 10.1016/ j.ijhm.2011.06.003.

Abrate, G., Quinton, S. and Pera, R. (2021), "The relationship between price paid and hotel review ratings: expectancy-disconfirmation or placebo effect?", Tourism Management, Vol. 85, p. 104314, doi: 10.1016/j.tourman.2021.104314.

Aksoy, S. and Ozbuk, M.Y. (2017), "Multiple criteria decision making in hotel location: does it relate to postpurchase consumer evaluations?”, Tourism Management Perspectives, Vol. 22, pp. 73-81, doi: 10.1016/j.tmp.2017.02.001.

Arora, A., Dahlströn, P., Hazan, E., Khan, H. and Khanna, R. (2020), "Reimagining marketing in the next normal", available at: https://www.mckinsey.com/business-functions/marketing-and-sales/ our-insights/reimagining-marketing-in-the-next-normal (accessed 3 August 2020). 
Aznar, J.P. (2020), "Differentiation and pricing strategies for hotels in sun and beach destinations", Managerial and Decision Economics, Vol. 42 No. 2, pp. 289-293, doi: 10.1002/mde.3234.

Becerra, M., Santalo, J. and Silva, R. (2013), "Being better vs. being different: differentiation, competition, and pricing strategies in the Spanish hotel industry", Tourism Management, Vol. 34, pp. 71-79, doi: 10.1016/j.tourman.2012.03.014.

Chen, C.F. and Rothschild, R. (2010), "An application of hedonic pricing analysis to the case of hotel rooms in Taipei”, Tourism Economics, Vol. 16 No. 3, pp. 685-694, doi: 10.5367/000000010792278310.

Chevalier, J.A. and Mayzlin, D. (2006), "The effect of word of mouth on sales: online book reviews", Journal of Marketing Research, Vol. 43 No. 3, pp. 345-354, doi: 10.1509/jmkr.43.3.345.

Chisholm, D.C., McMillan, M.S. and Norman, G. (2010), "Product differentiation and filmprogramming choice: do first-run movie theatres show the same films?", Journal of Cultural Economics, Vol. 34, pp. 131-145, doi: 10.1007/s10824-010-9118-y.

Chou, T.Y., Hsu, C.L. and Chen, M.C. (2008), "A fuzzy multi-criteria decision model for international tourist hotels location selection”, International Journal of Hospitality Management, Vol. 27 No. 2 , pp. 293-301, doi: 10.1016/j.ijhm.2007.07.029.

Clemons, E.K., Gao, G.G. and Hitt, L.M. (2006), "When online reviews meet hyperdifferentiation: a study of the craft beer industry", Journal of Management Information Systems, Vol. 23 No. 2, pp. 149-171, doi: 10.2753/MIS0742-1222230207.

Davison, A.C. and Hinkley, D.V. (1997), Bootstrap Methods and their Application (No. 1), Cambridge University Press, New York, NY.

De Langhe, B., Fernbach, P.M. and Lichtenstein, D.R. (2016), "Navigating by the stars: investigating the actual and perceived validity of online user ratings", Journal of Consumer Research, Vol. 42 No. 6, pp. 817-833, doi: 10.1093/jcr/ucv047.

Diehl, K. and Poynor, C. (2010), "Great expectations?! Assortment size, expectations, and satisfaction", Journal of Marketing Research, Vol. 47 No. 2, pp. 312-322, doi: 10.1509/jmkr.47.2.312.

Euromonitor (2018), “Top 100 city destinations 2018”, available at: https://www. europeancitiesmarketing.com/european-cities-marketing-benchmarking-report-2018-shows-thecontinuous-growth-of-european-city-tourism/ (accessed 2 July 2021).

European cities (2018), "European cities marketing benchmarking report 2018", available at: https:// go.euromonitor.com/white-paper-travel-2018-100-cities (accessed 7 July 2021).

Falk, M. and Hagsten, E. (2015), "Modelling growth and revenue for Swedish hotel establishments", International Journal of Hospitality Management, Vol. 45, pp. 59-68, doi: 10.1016/j.ijhm.2014. 11.009 .

Fang, L., Li, H. and Li, M. (2019), "Does hotel location tell a true story? Evidence from geographically weighted regression analysis of hotels in Hong Kong", Tourism Management, Vol. 72, pp. 78-91, doi: 10.1016/j.tourman.2018.11.010.

Filieri, R. and McLeay, F. (2014), "E-WOM and accommodation: an analysis of the factors that influence travelers' adoption of information from online reviews", Journal of Travel Research, Vol. 53 No. 1, pp. 44-57, doi: 10.1177/0047287513481274.

Flanagin, A.J. and Metzger, M.J. (2013), "Trusting expert- versus user-generated ratings online: the role of information volume, valence, and consumer characteristics", Computers in Human Behavior, Vol. 29 No. 4, pp. 1626-1634, doi: 10.1016/j.chb.2013.02.001.

Fuentes-Medina, M.L., Hernández-Estárico, E. and Morini-Marrero, S. (2018), "Study of the critical success factors of emblematic hotels through the analysis of content of online opinions: the case of the Spanish Tourist Paradors", European Journal of Management and Business Economics, Vol. 27 No. 1, pp. 42-65, doi: 10.1108/EJMBE-11-2017-0052.

García-Milon, A., Olarte-Pascual, C., Juaneda-Ayensa, E. and Pelegrín-Borondo, J. (2021), "Tourist purchases in a destination: what leads them to seek information from digital sources?", European Journal of Management and Business Economics, Vol. 30 No. 2, pp. 243-260, doi: 10. 1108/EJMBE-09-2019-0153.

Moderating effect of agglomeration 
EJMBE 31,2

Gretzel, U. and Yoo, K.H. (2008), "Use and impact of online travel reviews", in O'Connor, P., Höpken, W. and Gretzel, U.U. (Eds), Information and Communication Technologies in Tourism 2008. Springer, Vienna, pp. 35-46, doi: 10.1007/978-3-211-77280-5_4.

Gupta, S., McLaughlin, E. and Gomez, M. (2007), "Guest satisfaction and restaurant performance", Cornell Hotel and Restaurant Administration Quarterly, Vol. 48 No. 3, pp. 284-298, doi: 10.1177/ 0010880407301735 .

Gutt, D., Herrmann, P. and Rahman, M.S. (2019), "Crowd-driven competitive intelligence: understanding the relationship between local market competition and online rating distributions”, Information Systems Research, Vol. 30 No. 3, pp. 980-994, doi: 10.1287/isre. 2019.0845 .

Ho, Y.C., Wu, J. and Tan, Y. (2017), "Disconfirmation effect on online rating behavior: a structural model", Information Systems Research, Vol. 28 No. 3, pp. 626-642, doi: 10.1287/isre.2017.0694.

Hollebeek, L.D., Glynn, M.S. and Brodie, R.J. (2014), "Consumer brand engagement in social media: conceptualization, scale development and validation", Journal of Interactive Marketing, Vol. 28 No. 2, pp. 149-165, doi: 10.1016/j.intmar.2013.12.002.

Hollenbeck, B., Moorthy, S. and Proserpio, D. (2019), "Advertising strategy in the presence of reviews: an empirical analysis", Marketing Science, Vol. 38 No. 5, pp. 793-811, doi: 10.1287/mksc. 2019.1180.

HVS (2018), "HVS European hotel valuation index in-depth insights 2018”, available at: https:/hvs. com/article/8211-2018-european-hotel-valuation-index (accessed 2 July 2021).

Jang, S., Prasad, A. and Ratchford, B.T. (2012), "How consumers use product reviews in the purchase decision process", Marketing Letters, Vol. 23 No. 3, pp. 825-838, doi: 10.1007/s11002-012-9191-4.

Kannan, P.K. and Li, H.S. (2017), "Digital marketing: a framework, review and research agenda", International Journal of Research in Marketing, Vol. 34 No. 1, pp. 22-45, doi: 10.1016/j.jiresmar. 2016.11.006.

Kim, W.G., Lim, H. and Brymer, R.A. (2015), "The effectiveness of managing social media on hotel performance", International Journal of Hospitality Management, Vol. 44, pp. 165-171, doi: 10. 1016/j.ijhm.2014.10.014.

Kim, J.M., Jun, M. and Kim, C.K. (2018a), “The effects of culture on consumers' consumption and generation of online reviews", Journal of Interactive Marketing, Vol. 43, pp. 134-150, doi: 10. 1016/j.intmar.2018.05.002.

Kim, S., Kandampully, J. and Bilgihan, A. (2018b), "The influence of eWOM communications: an application of online social network framework", Computers in Human Behavior, Vol. 80, pp. 243-254, doi: 10.1016/j.chb.2017.11.015.

Kitirattarkarn, G.P., Tao, W. and Tsai, W.H.S. (2020), "Intended audience and valence of electronic word-of-mouth on social media: a study of Dutch consumers", Internet Research, Vol. 31 No. 3, pp. 990-1017, doi: 10.1108/INTR-03-2020-0133.

Ladhari, R. and Michaud, M. (2015), "eWOM effects on hotel booking intentions, attitudes, trust, and website perceptions", International Journal of Hospitality Management, Vol. 46, pp. 36-45, doi: 10.1016/j.ijhm.2015.01.010.

Lado-Sestayo, R., Otero-Gonzalez, L., Vivel-Bua, M. and Martorell-Cunill, O. (2016), "Impact of location on profitability in the Spanish hotel sector", Tourism Management, Vol. 52, pp. 405-415, doi: 10. 1016/j.tourman.2015.07.011.

Lappas, T., Sabnis, G. and Valkanas, G. (2016), "The impact of fake reviews on online visibility: a vulnerability assessment of the hotel industry", Information Systems Research, Vol. 27 No. 4, pp. 940-961, doi: 10.1287/isre.2016.0674.

Lee, S.K. (2015), "Quality differentiation and conditional spatial price competition among hotels", Tourism Management, Vol. 46, pp. 114-122, doi: 10.1016/j.tourman.2014.06.019.

Lee, S.K. and Jang, S. (2015), "Conditional agglomeration externalities in lodging markets", Journal of Hospitality and Tourism Research, Vol. 39 No. 4, pp. 540-559, doi: 10.1177/1096348013491605. 
Lee, M. and Youn, S. (2009), "Electronic word of mouth (eWOM). How eWOM platforms influence consumer product judgement”, International Journal of Advertising, Vol. 28 No. 3, pp. 473-499, doi: 10.2501/S0265048709200709.

Leung, X.Y. and Yang, Y. (2020), "Are all five points equal? Scaling heterogeneity in hotel online ratings", International Journal of Hospitality Management, Vol. 88, p. 102539, doi: 10.1016/j.ijhm. 2020.102539 .

Li, X. and Hitt, L.M. (2008), "Self-selection and information role of online product reviews", Information Systems Research, Vol. 19 No. 4, pp. 456-474, doi: 10.1287/isre.1070.0154.

Li, X. and Hitt, L.M. (2010), "Price effects in online product reviews: an analytical model and empirical analysis", Mis Quarterly, Vol. 34 No. 4, pp. 809-831, doi: 10.2307/25750706.

Li, X., Wu, C. and Mai, F. (2019), "The effect of online reviews on product sales: a joint sentiment-topic analysis", Information and Management, Vol. 56 No. 2, pp. 172-184, doi: 10.1016/j.im.2018. 04.007 .

Li, K., Chen, Y. and Zhang, L. (2020), "Exploring the influence of online reviews and motivating factors on sales: a meta -analytic study and the moderating role of product category", Journal of Retailing and Consumer Services, Vol. 55, p. 102107, doi: 10.1016/j.jretconser.2020.102107.

Li, H., Qi, R., Liu, H., Meng, F. and Zhang, Z. (2021), "Can time soften your opinion? The influence of consumer experience valence and review device type on restaurant evaluation", International Journal of Hospitality Management, Vol. 92, p. 102729, doi: 10.1016/j.ijhm.2020.102729.

Liberato, P., Alen, E. and Liberato, D. (2018), "Smart tourism destination triggers consumer experience: the case of Porto", European Journal of Management and Business Economics, Vol. 27 No. 1, pp. 6-25, doi: 10.1108/EJMBE-11-2017-0051.

Liu, A.X., Steenkamp, J.B.E. and Zhang, J. (2018), "Agglomeration as a driver of the volume of electronic word of mouth in the restaurant industry", Journal of Marketing Research, Vol. 55 No. 4, pp. 507-523, doi: 10.1509/jmr.16.0182.

Liu, S., Gao, B., Gallivan, M. and Gong, Y. (2020), "Free add-on services and perceived value in competitive environments: evidence from online hotel reviews", International Journal of Hospitality Management, Vol. 90, p. 102611, doi: 10.1016/j.jhm.2020.102611.

Lockyer, T. (2005), "The perceived importance of price as one hotel selection dimension”, Tourism Management, Vol. 26 No. 4, pp. 529-537, doi: 10.1016/j.tourman.2004.03.009.

Lovett, M.J., Peres, R. and Shachar, R. (2013), “On brands and word of mouth”, Journal of Marketing Research, Vol. 50 No. 4, pp. 427-444, doi: 10.1509/jmr.11.0458.

Lu, Y., Tao, Z. and Zhu, L. (2017), "Identifying FDI spillovers", Journal of International Economics, Vol. 107, pp. 75-90, doi: 10.1016/j.jinteco.2017.01.006.

Luca, M. and Zervas, G. (2016), "Fake it till you make it: reputation, competition, and Yelp review fraud", Management Science, Vol. 62 No. 12, pp. 3412-3427, doi: 10.1287/mnsc. 2015.2304.

Luo, H. and Yang, Y. (2016), "Intra-metropolitan location choice of star-rated and non-rated budget hotels: the role of agglomeration economies", International Journal of Hospitality Management, Vol. 59, pp. 72-83, doi: 10.1016/j.ijhm.2016.09.007.

Makadok, R. (2010), "The interaction effect of rivalry restraint and competitive advantage on profit: why the whole is less than the sum of the parts", Management Science, Vol. 56 No. 2, pp. 356-372, doi: $10.1287 / \mathrm{mnsc} .1090 .1102$.

Manes, E. and Tchetchik, A. (2018), "The role of electronic word of mouth in reducing information asymmetry: an empirical investigation of online hotel booking", Journal of Business Research, Vol. 85, pp. 185-196, doi: 10.1016/j.jbusres.2017.12.019.

Marco-Lajara, B., Claver-Cortes, E., Ubeda-Garcia, M. and del Carmen Zaragoza-Saez, P. (2016), “A dynamic analysis of the agglomeration and performance relationship", Journal of Business Research, Vol. 69 No. 5, pp. 1874-1879, doi: 10.1016/j.jbusres.2015.10.072. 
EJMBE 31,2

Martin-Fuentes, E. (2016), "Are guests of the same opinion as the hotel star-rate classification system?”, Journal of Hospitality and Tourism Management, Vol. 29, pp. 126-134, doi: 10.1016/ j.jhtm.2016.06.006.

Masiero, L. and Nicolau, J.L. (2016), "Choice behaviour in online hotel booking”, Tourism Economics, Vol. 22 No. 3, pp. 671-678, doi: 10.5367/te.2015.0464.

Masiero, L., Yang, Y. and Qiu, R.T. (2019), "Understanding hotel location preference of customers: comparing random utility and random regret decision rules", Tourism Management, Vol. 73, pp. 83-93, doi: 10.1016/j.tourman.2018.12.002.

Mayzlin, D., Dover, Y. and Chevalier, J. (2014), "Promotional reviews: an empirical investigation of online review manipulation”, American Economic Review, Vol. 104 No. 8, pp. 2421-2455, doi: 10. 1257/aer.104.8.2421.

McCann, B.T. and Folta, T.B. (2008), "Location matters: where we have been and where we might go in agglomeration research", Journal of Management, Vol. 34 No. 3, pp. 532-565, doi: 10.1177/ 0149206308316057.

Mona (2020), "What are the best arrondissements to stay at in Paris? Our comparison", available at: https://www.france-hotel-guide.com/en/blog/best-arrondissement-paris/ (accessed 15 January 2021).

Neirotti, P., Raguseo, E. and Paolucci, E. (2016), "Are customers' reviews creating value in the hospitality industry? Exploring the moderating effects of market positioning", International Journal of Information Management, Vol. 36 No. 6, pp. 1133-1143, doi: 10.1016/j.ijinfomgt.2016. 02.010 .

Nicholls, S. and Kim, J. (2019), "Spatial is special: the need to consider spatial effects in leisure research”, Leisure Sciences, pp. 1-21, doi: 10.1080/01490400.2019.1600441.

Nieto-Garcia, M., Munoz-Gallego, P.A. and Gonzalez-Benito, O. (2017), "Tourists' willingness to pay for an accommodation: the effect of eWOM and internal reference price", International Journal of Hospitality Management, Vol. 62, pp. 67-77, doi: 10.1016/j.ijhm.2016.12.006.

Oliver, R.L. (1980), "A cognitive model of the antecedents and consequences of satisfaction decisions", Journal of Marketing Research, Vol. 17 No. 4, pp. 460-469, doi: 10.1177/002224378001700405.

Öğ̈̈t, H. and Onur Taş, B.K. (2012), "The influence of internet customer reviews on the online sales and prices in hotel industry”, The Service Industries Journal, Vol. 32 No. 2, pp. 197-214, doi: 10. 1080/02642069.2010.529436.

Pantelidis, I.S. (2010), "Electronic meal experience: a content analysis of online restaurant comments", Cornell Hospitality Quarterly, Vol. 51 No. 4, pp. 483-491, doi: 10.1177/1938965510378574.

Park, S. and Nicolau, J.L. (2015), “Asymmetric effects of online consumer reviews”, Annals of Tourism Research, Vol. 50, pp. 67-83, doi: 10.1016/j.annals.2014.10.007.

Parsa, H., Self, J., Sydnor-Busso, S. and Yoon, H.J. (2011), "Why restaurants fail? Part II-The impact of affiliation, location, and size on restaurant failures: results from a survival analysis", Journal of Foodservice Business Research, Vol. 14 No. 4, pp. 360-379, doi: 10.1080/15378020.2011.625824.

Pearce, D.G. (1999), “Tourism in Paris studies at the microscale”, Annals of Tourism Research, Vol. 26 No. 1, pp. 77-97, doi: 10.1016/S0160-7383(98)00051-6.

Pinkse, J., Slade, M.E. and Brett, C. (2002), "Spatial price competition: a semiparametric approach", Econometrica, Vol. 70 No. 3, pp. 1111-1153, doi: 10.1111/1468-0262.00320.

Plotkina, D. and Munzel, A. (2016), "Delight the experts, but never dissatisfy your customers! A multicategory study on the effects of online review source on intention to buy a new product", Journal of Retailing and Consumer Services, Vol. 29, pp. 1-11, doi: 10.1016/j.jretconser.2015. 11.002.

Prentice, C., Wang, X. and Loureiro, S.M.C. (2019), "The influence of brand experience and service quality on customer engagement", Journal of Retailing and Consumer Services, Vol. 50, pp. 50-59, doi: 10.1016/j.jretconser.2019.04.020. 
Radojevic, T., Stanisic, N. and Stanic, N. (2017), "Inside the rating scores: a multilevel analysis of the factors influencing customer satisfaction in the hotel industry", Cornell Hospitality Quarterly, Vol. 58 No. 2, pp. 134-164, doi: 10.1177/1938965516686114.

Ritter, W. (1986), "Hotel location in big cities", in Vetter, F. (ed.), Big City Tourism, Reimer Verlag, Berlin, pp. 355-364.

Rosario, A.B., De Valck, K. and Sotgiu, F. (2020), "Conceptualizing the electronic word-of-mouth process: what we know and need to know about eWOM creation, exposure, and evaluation", Journal of the Academy of Marketing Science, Vol. 48 No. 3, pp. 422-448, doi: 10.1007/s11747-01900706-1.

Ruiz-Mafe, C., Bigné-Alcañiz, E. and Currás-Pérez, R. (2020), "The effect of emotions, eWOM quality and online review sequence on consumer intention to follow advice obtained from digital services", Journal of Service Management, Vol. 31 No. 3, pp. 465-487, doi: 10.1108/JOSM-112018-0349.

Sanchez-Perez, M., Dolores Illescas-Manzano, M. and Martinez-Puertas, S. (2020), "You're the only one, or simply the best. Hotels differentiation, competition, agglomeration, and pricing", International Journal of Hospitality Management, Vol. 85, p. 102362, doi: 10.1016/j.ijhm.2019. 102362.

Shaked, A. and Sutton, J. (1982), "Relaxing price-competition through product differentiation", Review of Economic Studies, Vol. 49 No. 1, pp. 3-13, doi: 10.2307/2297136.

Shoval, N., McKercher, B., Ng, E. and Birenboim, A. (2011), "Hotel location and tourist activity in cities", Annals of Tourism Research, Vol. 38 No. 4, pp. 1594-1612, doi: 10.1016/j.annals.2011. 02.007 .

Silva, R. (2015), "Multimarket contact, differentiation, and prices of chain hotels", Tourism Management, Vol. 48, pp. 305-315, doi: 10.1016/j.tourman.2014.11.006.

So, K.K.F., King, C., Sparks, B.A. and Wang, Y. (2016), "The role of customer engagement in building consumer loyalty to tourism brands", Journal of Travel Research, Vol. 55 No. 1, pp. 64-78, doi: $10.1177 / 0047287514541008$.

Statista (2020), “Attitudes towards online shopping in France 2020", available at: https://www.statista. com/forecasts/998225/attitudes-towards-online-shopping-in-france (accessed 20 December 2020).

Stojanovic, I., Andreu, L. and Curras-Perez, R. (2018), "Effects of the intensity of use of social media on brand equity", European Journal of Management and Business Economics, Vol. 27 No. 1, pp. 83-100, doi: 10.1108/EJMBE-11-2017-0049.

Tiago, F., Gil, A., Stemberger, S. and Borges-Tiago, T. (2021), "Digital sustainability communication in tourism”, Journal of Innovation and Knowledge, Vol. 6 No. 1, pp. 27-34, doi: 10.1016/j.jik.2019. 12.002 .

Tiberius, V., Schwarzer, H. and Roig-Dobón, S. (2021), "Radical innovations: between established knowledge and future research opportunities", Journal of Innovation and Knowledge, Vol. 6 No. 3, pp. 145-153, doi: 10.1016/j.jik.2020.09.001.

Todri, V., Adamopoulos, P. and Andrews, M. (2021), "Express: is distance really dead in the online world? The moderating role of geographical distance on the effectiveness of electronic word-ofmouth", Journal of Marketing. doi: 10.1177/00222429211034414.

Torres, E.N., Adler, H. and Behnke, C. (2014), "Stars, diamonds, and other shiny things: the use of expert and consumer feedback in the hotel industry", Journal of Hospitality and Tourism Management, Vol. 21, pp. 34-43, doi: 10.1016/j.jhtm.2014.04.001.

Turkina, E., Oreshkin, B. and Kali, R. (2019), "Regional innovation clusters and firm innovation performance: an interactionist approach”, Regional Studies, Vol. 53 No. 8, pp. 1193-1206, doi: 10. 1080/00343404.2019.1566697.

Urtasun, A. and Gutierrez, I. (2017), "Clustering benefits for upscale urban hotels", International Journal of Contemporary Hospitality Management, Vol. 29 No. 5, pp. 1426-1446, doi: 10.1108/ IJCHM-10-2015-0583. 
EJMBE 31,2

Van Doorn, J., Lemon, K.N., Mittal, V., Nass, S., Pick, D., Pirner, P. and Verhoef, P.C. (2010), “Customer engagement behavior: theoretical foundations and research directions", Journal of Service Research, Vol. 13 No. 3, pp. 253-266, doi: 10.1177/1094670510375599.

Varki, S. and Colgate, M. (2001), "The role of price perceptions in an integrated model of behavioral intentions", Journal of Service Research, Vol. 3 No. 3, pp. 232-240, doi: 10.1177/109467050133004.

Verma, S. and Yadav, N. (2021), "Past, present, and future of electronic word of mouth (EWOM)", Journal of Interactive Marketing, Vol. 53, pp. 111-128, doi: 10.1016/j.intmar.2020.07.001.

Viglia, G., Minazzi, R. and Buhalis, D. (2016), "The influence of e-word-of-mouth on hotel occupancy rate", International Journal of Contemporary Hospitality Management, Vol. 28 No. 9, pp. 2035-2051, doi: 10.1108/IJCHM-05-2015-0238.

Voelckner, F. and Hofmann, J. (2007), "The price-perceived quality relationship: a meta-analytic review and assessment of its determinants", Marketing Letters, Vol. 18 No. 3, pp. 181-196, doi: 10.1007/ s11002-007-9013-2.

Wakefield, L.T. and Wakefield, R.L. (2018), "Anxiety and ephemeral social media use in negative ewom creation”, Journal of Interactive Marketing, Vol. 41, pp. 44-59, doi: 10.1016/j.intmar.2017. 09.005.

Wolinsky, A. (1983), "Prices as signals of product quality", Review of Economic Studies, Vol. 50 No. 4, pp. $647-658$, doi: 10.2307/2297767.

Xie, K.L., Zhang, Z., Zhang, Z., Singh, A. and Lee, S.K. (2016), "Effects of managerial response on consumer ewom and hotel performance", International Journal of Contemporary Hospitality Management, Vol. 28 No. 9, pp. 2013-2034, doi: 10.1108/IJCHM-06-2015-0290.

$\mathrm{Xu}, \mathrm{X}$. and Li, Y. (2016), "The antecedents of customer satisfaction and dissatisfaction toward various types of hotels: a text mining approach", International Journal of Hospitality Management, Vol. 55, pp. 57-69, doi: 10.1016/j.ijhm.2016.03.003.

Xue, F., Dong, L., Gao, B., Yu, Z. and Taras, V. (2020), "Understanding the relationships between distances and herd behavior in online reviews: the moderating effects of hospitality experience", International Journal of Contemporary Hospitality Management, Vol. 32 No. 10, pp. 3295-3314, doi: 10.1108/IJCHM-02-2020-0134.

Yang, Y., Wong, K.K. and Wang, T. (2012), "How do hotels choose their location? Evidence from hotels in Beijing”, International Journal of Hospitality Management, Vol. 31 No. 3, pp. 675-685, doi: 10. 1016/j.ijhm.2011.09.003.

Yang, Y., Luo, H. and Law, R. (2014), "Theoretical, empirical, and operational models in hotel location research", International Journal of Hospitality Management, Vol. 36, pp. 209-220, doi: 10.1016/j. ijhm.2013.09.004.

Yang, Y., Mao, Z. and Tang, J. (2018a), "Understanding guest satisfaction with urban hotel location”, Journal of Travel Research, Vol. 57 No. 2, pp. 243-259, doi: 10.1177/0047287517691153.

Yang, Y., Park, S. and Hu, X. (2018b), "Electronic word of mouth and hotel performance: a metaanalysis", Tourism Management, Vol. 67, pp. 248-260, doi: 10.1016/j.tourman.2018.01.015.

Ye, Q., Li, H., Wang, Z. and Law, R. (2014), "The influence of hotel price on perceived service quality and value in e-tourim: an empirical investigation based on online traveler reviews", Journal of Hospitality and Tourism Research, Vol. 38 No. 1, pp. 23-39, doi: 10.1177/1096348012442540.

Yen, C.L.A. and Tang, C.H.H. (2019), "The effects of hotel attribute performance on electronic word-ofmouth (eWOM) behaviors", International Journal of Hospitality Management, Vol. 76, pp. 9-18, doi: 10.1016/j.ijhm.2018.03.006.

Yoon, Y., Kim, A.J., Kim, J. and Choi, J. (2019), "The effects of eWOM characteristics on consumer ratings: evidence from tripadvisor.com", International Journal of Advertising, Vol. 38 No. 5, pp. 684-703, doi: 10.1080/02650487.2018.1541391.

You, Y., Vadakkepatt, G.G. and Joshi, A.M. (2015), "A meta-analysis of electronic word-of-mouth elasticity”, Journal of Marketing, Vol. 79 No. 2, pp. 19-39, doi: 10.1509/jm.14.0169. 
Zhang, Z., Zhang, Z. and Law, R. (2014), "Positive and negative word of mouth about restaurants: exploring the asymmetric impact of the performance of attributes", Asia Pacific Journal of Tourism Research, Vol. 19 No. 2, pp. 162-180, doi: 10.1080/10941665.2012.735680.

Zhu, D.H., Zhang, Z.J., Chang, Y.P. and Liang, S. (2019), "Good discounts earn good reviews in return? Effects of price promotion on online restaurant reviews", International Journal of Hospitality Management, Vol. 77, pp. 178-186, doi: 10.1016/j.ijhm.2018.06.028.

\section{Corresponding author}

Sergio Martínez-Puertas can be contacted at: spuertas@ual.es

For instructions on how to order reprints of this article, please visit our website:

www.emeraldgrouppublishing.com/licensing/reprints.htm

Or contact us for further details: permissions@emeraldinsight.com 